\title{
Dileme și provocări în sprijinirea cursurilor de etică, deontologie și integritate academică ${ }^{1}$
}

\section{Gabriel-Stănică LUPU1*}

Citation: Lupu, G.S. (2021). Dileme și provocări în sprijinirea cursurilor de etică, deontologie și integritate academică. Revista Etică şi Deontologie. 1(1), 44-51 https://doi.org/10.52744/RED.2021.01.06

Publisher's Note: RED stays neutral with regard to jurisdictional claims in published maps and institutional affiliations.

\section{(c) (1)}

Copyright: (C) 2021 by the authors. Submitted for possible open access publication under the terms and conditions of the Creative Commons Attribution (CC BY) license (https://creativecommons.org/ licenses/by/4.0/).
1 Universitatea Vasile Alecsandri din Bacău, gabi.lupu@ub.ro

* Correspondent: gabi.lupu@ub.ro

Rezumat: Societatea informațională și globalizarea aduc, precum orice tendință și schimbare majoră în istoria umană, avantaje și dezavantaje pentru individ și pentru întreaga societate. Odată cu circulația extrem de rapidă a informației, cu creșterea accesului la baze de date uriașe, cu apariția mijloacelor de comunicare la distanță care permit părților implicate să interacționeze în timp real, să transfere volume mari de date, au apărut și situații în care persoane individuale sau grupuri, au abuzat de aceste facilități și le-au exploatat în scopuri lipsite de responsabilitate etică, afectând instituții, specialiști din mediul academic, indivizi din diverse zone profesionale, atât din punct de vedere al imaginii, cât și patrimonial.

Formarea și integrarea viitorilor specialiști pe piața muncii, în economie, în educație, în sănătate sau în administrație, necesită nu doar bagajul de cunoștințe aferent domeniului de studiu. Este nevoie de formarea unor comportamente, caractere și atitudini adecvate privitoare la integritate, etică, deontologie profesională. Acest lucru se obține prin educarea, conștientizarea și stimularea tinerilor, în vederea construirii valorilor morale până la virtuți, astfel încât să aibă un aport crescut la performanța unității în care își desfășoară activitatea, concomitent cu îmbunătățirea culturii organizaționale din care fac parte. Nu toți studenții vor activa în cercetare sau în educație. Acest lucru nu este relevant atunci când vorbim de necesitatea formării unor comportamente etice pe termen lung. Studentul de azi, viitorul profesionist, poate fi un serios element de influență pozitivă și formare adecvată a generațiilor următoare, de la catedră, din mediul de afaceri, dintr-o întreprindere sau dintr-o instituție publică.

Cuvinte cheie: academic, educație, etică, morală, valori

${ }^{1}$ Articol prezentat în cadrul Conferinței Internaționale Valorile Etice în Societatea Actuală - VESA 2021 (3-5 iunie). 


\section{Introducere}

Evoluția sistemului de studii superioare din România a cunoscut suișuri și coborâșuri, ca orice zonă de activitate umană. Educația, concept și sistem, se pare că a înregistrat un regres după 1989, când au apărut și entități în domeniul educațional care, în goana după educabili plătitori, au coborât ștacheta și au făcut concesii, facilitând propagarea în societate a ideii că a avea studii, chiar de nivel superior, nu mai este un privilegiu pentru care este necesar să muncești din greu, o diplomă putându-se cumpăra cu ușurință dacă dispui de resursele necesare. Această percepție care mai dăinuie din nefericire și astăzi, este greu de anihilat, lupta împotriva ei dovedindu-se una dificilă, de „guerilă”, cu mici victorii și cu fiecare pas înainte făcut cu mari eforturi. Nu este obiectivul nostru în această lucrare să analizăm cauzele ce sunt multiple și care nu pot fi tratate singular, pentru că nu se va obține altfel rezultatul scontat.

Reconstrucția sistemului universitar de studii constă, ca întotdeauna, în capacitatea resursei umane, de a avea răbdarea și perseverența necesare pentru a promova în mod constant valorile științifice și etice care au făcut ca universități precum cea din Bologna, înființată în anul 1088, ori cea din Oxford, despre care se știe cu certitudine că deja exista în anul 1167, să existe și astăzi. Nevoia unor valori etice bine așezate în psihicul uman nu se remarcă doar la nivel universitar, ci și în profesii dinafara sistemului de educație, de fapt, în orice ocupație. De aceea astăzi, mai mult ca niciodată, este necesar să asigurăm o bună informare și pregătire a viitorilor profesioniști, cât mai devreme și cât mai temeinic, astfel încât acțiunile acestora să fie validate și prin respectarea regulilor etice și a valorilor umane, pentru că numai așa progresul societății va fi asigurat. Ideea de educație morală, de inoculare a unor valori umane universal valabile, nu este nouă. Mare parte din acest tip de formare are loc în familie și în grupul social. Nu vom face un istoric al acestui tip de educație, ce își găsește sorgintea în antichitate (Socrate, Platon, Aristotel), ci vom aminti de sistemul românesc de învățământ care avea în program o astfel de curriculă pentru

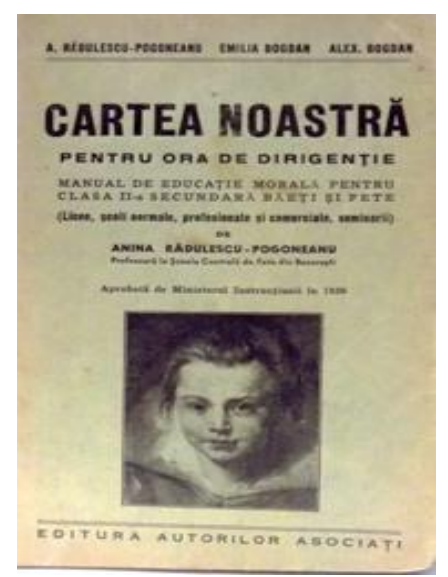

Figura. 1 - Manual de educație morală pentru ora de dirigenție, nivel liceu, şcoli normale şi profesionale, 1938 


\section{$\underset{\text { ETI }}{\text { ETICĂ }}$

nivelul liceal (fig. 1), cu aprobarea Ministerului Educației, în perioada regalistă. De asemenea, în cadrul orelor de dirigenție, temele conțineau educația morală ca filon central (fig. 2).

Nimic nou sub soare deci. Tinerii se formează în timp ca viitori cetățeni și profesioniști, din acest motiv și educația morală și etică trebuie să înceapă cât mai devreme.

\section{Analiza cadrului actual de educație etică și morală}

Astfel, curriculum-ul actual prevede module de comportamente morale și civice încă de la clasa a

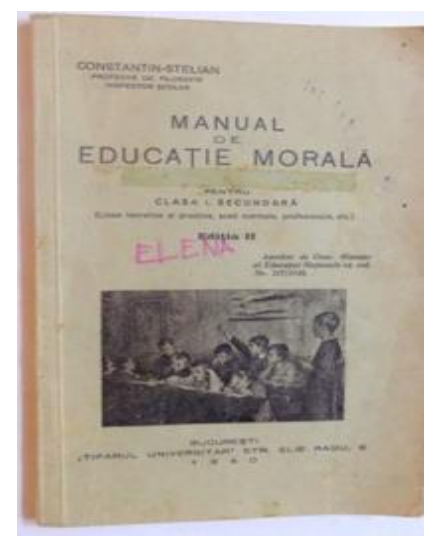

Figura. 2 - Manual de educație morală, nivel liceu, şcoli normale şi profesionale, 1940 IV-a, noțiuni care sunt continuate la nivel de învățământ gimnazial.

În liceu nu există în curriculum o disciplină care să se studieze astăzi la toate tipurile de învățământ liceal. Există un modul în învățământul profesional și tehnic, denumit „Etică și comunicare profesională”, ce conține și noțiuni de etică profesională. Rămâne deci în sarcina universităților să formeze resursa umană de mâine și în această direcție.

În opinia noastră, este nevoie în învățământul liceal de un calup mai consistent de astfel de noțiuni, cuprinse într-o disciplină dedicată și nu presărate în diferite alte discipline, pentru că profesioniștii de mâine nu sunt doar cei care absolvă o facultate.

De ce totuși, la nivel universitar, este nevoie de o educaţie etică solidă? Motivele sunt multe și toate sunt raportate la rezultatele obținute, atât în formarea studenților, cât și în cercetare și în aplicarea rezultatelor cercetărilor desfășurate în economie, industrie sau în zona socială. Schimbarea unor tipare comportamentale nu poate veni decât din educație și prin educație. Să determini studentul să iasă din zona de confort, să depună sistematic efort pentru a obține rezultate bune în evaluările semestriale ori anuale, să aducă plus valoare prin lucrările sau proiectele pe care le întocmește, este un demers extrem de dificil, în condiţiile în care el are acces nelimitat la informație pe Internet, iar societatea, pe diferite canale, îi transmite, uneori subliminal, că acest efort este inutil. Conștientizarea studentului care va fi mâine specialist, profesor, cercetător că munca sa contează, că educația îi va aduce recompensa în viitor, este o țintă greu de atins, însă este una obligatorie, mai ales că unele efecte au și reflectare financiară (de exemplu, drepturile de autor).

În acest sens, foarte utile sunt reglementările în domeniul etic, fie că sunt coduri de etică academică, regulamente ale studentului, prevederi legislative, module de studiu ori discipline. 
Partea bună este aceea că și la nivel legislativ, au fost aprobate reglementări care definesc abaterile de la etică și care prevăd și sancțiunile aferente. Legea educației naționale nr. 1/2011 cu modificările și completările ulterioare (Lege, 2011) prevede la art. 130 alin. (1) lit. a) b) și c), că universitățile au obligativitatea de a adopta coduri de etică și deontologie profesională, de a stabili și elimina conflictele de interese, dar și de a lua măsuri pentru a se asigura de originalitatea lucrărilor de licență, master ori doctorat pe care le acceptă pentru susținere, a articolelor științifice sau a altor rezultate ale activității academice, care sunt comunicate sau publicate. $\mathrm{Nu}$ este însă definit conceptul de „originalitate”, iar cea mai des întâlnită abatere la acest nivel este plagiatul. În acest caz, sintagma „originalitate” este un element discutabil atunci când ne gândim la o lucrare de licență, ori chiar de master.

Legea nr. 206/27.05.2004 privind buna conduită în cercetarea științifică, dezvoltarea tehnologică și inovare, cu modificările şi completările ulterioare (Lege, 2004), coroborată cu Legea nr. 319/08.07.2003 privind statutul personalului de cercetare-dezvoltare (Lege, 2003), definesc categoriile de personal care pot fi subiectul faptelor de plagiat sau autoplagiat (Matic, 2018, p. 78):

- personalul de cercetate-dezvoltare,

- cadrele didactice universitare,

- personalul auxiliar din activitatea de cercetare-dezvoltare,

- personalul din aparatul functional,

- alte categorii de personal din mediul public și privat, care beneficiază de fonduri publice de cercetare-dezvoltare.

De asemenea, în regulamentul școlilor doctorale, prevăzut în HG 681/29.06.2011 privind aprobarea Codului studiilor universitare de doctorat, la art. 17 alin. 5 lit. e) se specifică faptul că în regulamentul școlii doctorale trebuie să stabilească criterii, proceduri și standarde obligatorii vizând și modalitățile de prevenire a fraudei în cercetarea științifică, inclusiv plagiatul (Hotărâre, 2011).

Iată deci că, referitor la studiile de licență ori de master, nu face referire decât Legea educației naționale, așa cum am amintit anterior, dar fără a fi explicită privitor la cum trebuie evaluat nivelul de originalitate. Deschidem aici această discuție pentru că în mediul universitar, în cărțile și cursurile de etică și deontologie academică se face referire în mod exhaustiv la plagiat și autoplagiat. Nu trebuie să uităm însă că o lucrare de licență nu este menită să aducă noutăți ori modificări de abordare într-un domeniu de studii, ci trebuie să arate fără putință de tăgadă că studentul ori masterandul care s-a înscris la examenul de finalizare a studiilor, a dobândit cunoștințele necesare și diploma vine să confirme acest lucru, în fața oricui. Astfel, o lucrare de licență sau chiar de masterat, reprezintă perspectiva unică a studentului privitor la modul în care problematica din subiectul lucrării a fost abordată, perspectivă susținută de referințele și citările din sursele bibliografice consultate.

Aici rămâne deschisă discuția dacă o lucrare de acest nivel trebuie verificată cu un soft antiplagiat, care nu poate face distincția, așa cum un om o poate face, ci doar subliniază corespondența dintre textul analizat și sursele accesibile de pe Internet. Ne gândim la acest lucru din perspectiva faptului că și alți autori sunt de părere că 
trebuie analizat cu atenție și evaluată corect noțiunea de originalitate la lucrările de licență și de master (Matic, 2018, p. 80). Un cercetător are obligatoriu un nivel înalt al simțului responsabilității și își asumă rezultatele cercetărilor sale și comunicărilor sale publice. În cazul în care acestea sunt false, consecințele sunt grave, atât pentru cel în cauză, cât și pentru instituția de învățământ sau cercetare unde acesta își desfășoară activitatea. Consecințele pot fi atât materiale, cât și de imagine și prestigiu.

Un student este, în demersul întocmirii lucrării sale de licență, însoțit constant, de la debut, până la finalizare, de către profesorul îndrumător care îi verifică periodic, în fiecare etapă, rezultatul muncii, îl coordonează și consiliază, astfel că abaterile de orice tip pot fi identificate și se poate face o prevenție a apariției unor cazuri de plagiat. Apreciez ca este usor nefiresc ca studentul să finalizeze lucrarea, să obțină acordul profesorului pentru forma finală și să fie respins la verificarea antiplagiat. Chiar și așa, rapoartele generate de aceste softuri trebuie analizate și stabilit dacă ceea ce apare ca plagiat nu poate să se situeze în zona noțiunilor, termenilor, definițiilor care se regăsesc în mod obligatoriu în domeniul teoretic al câmpului științific respectiv. Nu vrem să dăm de înțeles că suntem împotriva acestor verificări. Lucrarea de licență este un act major al studentului/masterandului și acesta trebuie să trateze momentul final de evaluare, la încheierea studiilor universitare, cu cea mai mare seriozitate. Vrem doar să ne exprimăm opinia că, mai ales în cazul lucrărilor de licență, acel procent de plagiat care rezultă, ar trebui analizat cu foarte mare atenție și determinat dacă este într-adevăr un furt din cercetările și publicațiile altor autori și mai ales, dacă acest furt a fost comis cu intenție, sau nu (Singer, 2006, p. 212). Subliniem încă odată că studentul este coordonat și monitorizat de către profesorul îndrumător care ar trebui să atragă atenția si să-i arate studentului unde greșește sau unde crede că lucrarea este suspectă de plagiat sau de lipsă de originalitate.

Totuși, atunci când vorbim despre etică, integritate și deontologie academică, nu vorbim doar despre plagiat, deși acesta este în centrul atenţiei. În cadrul activităților desfășurate în mediul universitar, atât de către studenți și masteranzi, cât și de personalul didactic și nedidactic, există o serie întreagă de comportamente care fie sunt la limita eticii și deontologiei profesionale, fie o încalcă. Personalul didactic șia asumat o misiune complexă și de durată prin aderarea la corpul profesoral, atât din perspectiva formării științifice a viitorului specialist, cât și din perspectiva formării sale umane și cetățenești. Profesorul are un impact deosebit asupra studentului, în primul rând prin modelul uman pe care îl oferă și îl promovează. Memoria umană funcționează după legități și procese pe care abia astăzi reușim să le dezvăluim și să le înțelegem. Amintim acest lucru în contextul de față deoarece mulți specialiști sunt de părere că memoria colectează pe termen lung elementele care au impresionat profund, pozitiv sau negativ, omul (Cury, 2005). Din această perspectivă devine ușor de înțeles de ce un profesor exigent la catedră, dar deschis în discuții, care oferă sprijin 
și care consiliază studentul cu toată priceperea sa, devine un model care va fi copiat de marea majoritate a „ucenicilor” săi. Aceștia nu numai că își vor aminti cu afecțiune de acel profesor, ci inconștient îi vor copia comportamentele care i-au impresionat atât de mult. La fel, un model uman negativ, deși nu este de dorit, va fi copiat de o altă parte dintre învățăcei pentru că ei văd că, dacă unei persoane cu un astfel de statut i se permit comportamente lipsite de etică și de profesionalism, înseamnă că se poate și că pot proceda la fel. Profesorul este, vrând-nevrând, în centrul atenției și este un element de referință în formarea studentului ca viitor specialist, cetățean implicat și responsabil. Iată de ce, cuvântul cheie în activitatea de influențare pe care profesorul o exercită asupra studentului, trebuie să fie cuvântul „trebuie”. Acest cuvânt derivă din existența codurilor etice și a celorlalte reglementări care trebuie respectate, studentul trebuie format după legități obiective, ferme, așa cum și Kant afirma în prelegerile sale universitare în anul 1784 (Mureșan, 2007), când spunea că aceste reguli obiective ne determină să nu facem ceea ce dorim, ci ceea ce trebuie. Așa cum se specifică și în codurile etice ale altor profesii, în cazul de față cu atât mai mult este necesar ca profesorul să aibă tăria de a trece peste interesul personal și de a fi integru și mereu egal cu el însuși în abordarea diferitelor situații cu care se confruntă. Trebuie să recunoaștem cu onestitate că nu poți cere altui semen să facă, ori se comporte întrun anumit mod, dacă tu nu ești capabil să îi oferi un model comportamental în acest sens și, mai mult, nu ești mereu consecvent în aceste comportamente. Un comportament ghidat de etică și integritate, verticalitate, onestitate, va primi drept feedback din partea studentului ceea ce numim în limbaj obișnuit „respect”. Atunci când un profesor este respectat, studentul îl transformă într-un element de referință, de modelare și evaluare a propriilor comportamente, îi promovează abordările, conduita și atitudinea. Ori, trebuie să recunoaștem, un profesor respectat este un cod etic viu, un curs continuu la care au, indiferent de orar, acces toți studenții săi.

Desigur că absența comportamentelor etice va fi sancționată de două ori, atât prin sancțiunile formale cuprinse în reglementările legislative și în codurile de etică, cât și prin schimbarea atitudinii studenților față de respectivul cadru didactic.

0 altă provocare vine din nevoia de a măsura efectele educației etice și aici ne referim nu la notarea în cadrul unui colocviu ori examen, ci la măsura în care sunt implementate comportamente etice permanente la profesioniștii care au absolvit studiile universitare și își desfășoară activitatea în câmpul profesional pe care și l-au ales. Cum știm că, dincolo de răspunsurile la un examen sau un chestionar unde fie sunt reproduse niște noțiuni, fie sunt date de multe ori, răspunsuri care sunt din categoria celor „politic” corecte, respectiv sunt oferite răspunsurile pe care studentul crede că profesorul său le așteaptă, se formează atitudini, abilități și comportamente bine ancorate? 


\section{Concluzii}

Opinia noastră este că cea mai mare provocare este aceasta: cum ne asigurăm că am creat abilități pentru toată viața și comportamentele etice sunt permanente. În primul rând nu toți studenții care termină anual cursurile universitare pot fi urmăriți în carieră, este un proces dificil și nu există instrumente standardizate și obiective în acest sens. În al doilea rând, multe situații în care apar comportamente ce încalcă etica și deontologia profesională nu sunt raportate, sunt acoperite, neglijate sau chiar li se dă o tușă de normalitate, astfel încât este greu de cuantificat rata de apariție a comportamentelor lipsite de integritate sau deontologie profesională, după ce studentul părăsește sistemul educațional. Credem deci că este extrem de dificil de asigurat un sistem de feedback postuniversitar, astfel încât să putem să folosim acele informații ca input pentru îmbunătățirea cursului și a activităților de seminar. Actualmente nu avem decât posibilitatea de a aplica eventual un chestionar foștilor studenți pe care îi putem contacta după o anumită perioadă de la finalizarea studiilor. Din punct de vedere statistic însă, este dificilă constituirea unui eșantion reprezentativ, deoarece respondenții nu vor putea fi selectați în mod aleatoriu, ci vor fi procesate răspunsurile celor care vor putea fi contactați și care vor accepta să participe la survey. Mai mult, mărimea eșantionului probabil nu va putea fi atinsă. Și aici ne izbim de problema răspunsurilor de tipul „politically correct”, astfel că este foarte posibil ca datele colectate să ne ofere o imagine falsă a situației.

Insistăm asupra acestui lucru deoarece, așa cum formăm abilități și competențe științifice și tehnice, tot așa trebuie să formăm și atitudini și competențe pentru viață, iar acestea se transferă și în domeniul social și personal, îmbunătățind calitatea vieții individului și a societății din care face parte.

O altă soluție ar fi să putem contacta angajatorii foștilor studenți și să îi rugăm să răspundă la un chestionar. În acest caz, chestionarul ar trebui conceput și testat de către un grup de specialiști, printre care să se afle și un sociolog/psiholog, astfel încât să poată fi formulat un set de întrebări, reduse ca număr (ne gândim că nimeni nu dorește să dedice timp și energie pentru a completa un formular, fără nici un feedback/finalitate/recompensă), dar relevante din punct de vedere al conținutului, astfel încât atunci când formulăm concluziile studiului, acestea să fie cuprinzătoare, relevante și cu un coeficient redus de eroare.

De asemenea, poate că ar putea fi organizate sesiuni de comunicări între universitate și angajatori, astfel ca în cadrul discuțiilor ce se desfășoară, să poate fi făcut și un schimb de informații și în domeniul etic, respectiv specificități ale domeniului de activitate, tipuri de cazuri de abatere de la normele și codurile etice ale domeniului profesional, instrumente de soluționare și de prevenire, eventual un cod comun de bune practici, care să valorifice atât experiența universitară, predominant 
teoretică, informativă, cât și cea aplicată, a angajatorului, care poate reflecta o parte din feedbackul de care avem nevoie în demersul nostru educaţional.

\section{Referințe}

Cury, A. (2005). Părinți străluciți, profesori fascinanți - Cum să formăm tineri fericiți și inteligenți. București, Editura For You.

Lege. (2003). Legea nr. 319/08.07.2003 privind statutul personalului de cercetare-dezvoltare, M.Of. 530 din 23 iulie 2003, disponibilă la: http://legislatie.just.ro/Public/Detalii Document/45166

Lege. (2004). Legea nr. 206/27.05.2004 privind buna conduită în cercetarea științifică, dezvoltarea tehnologică și inovare, M.Of. 505 din 4 iunie 2004, disponibilă la: http://legislatie.just.ro/Public/DetaliiDocument/52457

Lege. (2011). Legea educației naționale nr. 1/2011, M.Of. 18 din 10 ianuarie 2011, disponibilă la: http://legislatie.just.ro/Public/DetaliiDocument/125150. Hotărâre. (2011). HG 681 din 29.06.2011 privind aprobarea Codului studiilor universitare de doctorat, M.Of. 681 din 29 iunie 2011, disponibilă la: http://legislatie.just.ro/Public/DetaliiDocument/130547

Matic, A.V., (2018), Plagiatul, autoplagiatul și alte abateri de la normele de bună conduită în cercetarea știinșifică, dezvoltarea tehnologică și inovare. În C.C. Vlad, Etică și deontologie academică (pp. 59-117). Galați: Editura Universității din Galați.

Mureșan, V., (2007), Comentariu la Întemeierea metafizicii moravurilor. În I. Kant, Întemeierea metafizicii moravurilor (pp. 187-410). București Editura Humanitas.

Singer, P., (2006). Tratat de etică. Iași, Editura Polirom.

\section{Surse imagini:}

Fig. 1: https://www.anticariat-unu.ro/manual-de-educatie-morala-pentru-clasa-i-secundarade-constantin-stelian-1940-p144023;

Fig. 2: https://www.anticariat-unu.ro/cartea-noastra-pentru-ora-de-dirigentie-manual-deeducatie-morala-pentru-clasa-a-ii-a-secundara-baieti-si-fete-de-a-radulescupogoneanu-emilia-bogdan-alex-bogdan-1936-p133877 